
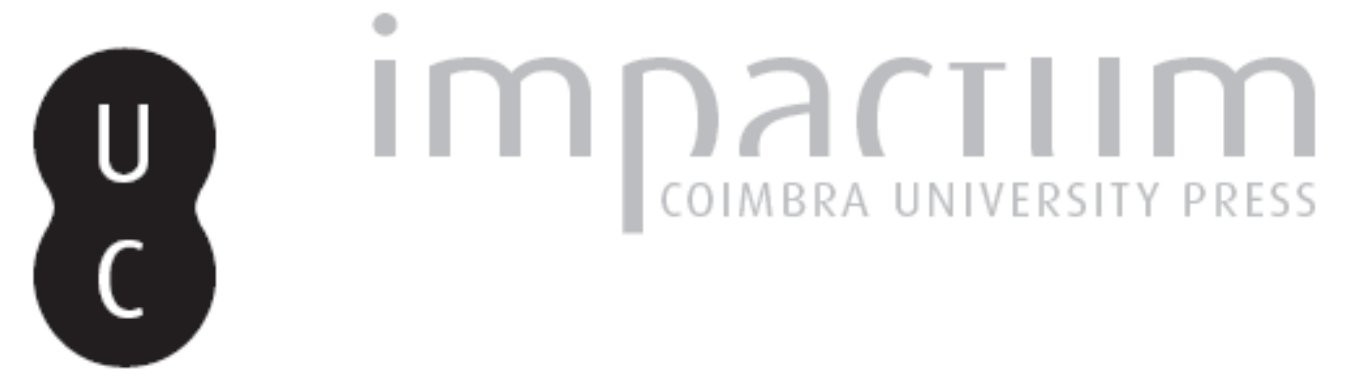

\title{
[Recensão a] Adrienne Mayor (2014), The Amazons: Lives and Legends of Warrior Women across the Ancient World
}

Autor(es): $\quad$ Magalhães, José Malheiro

Publicado por: Centro de História da Universidade de Lisboa

URL persistente:

URI:http://hdl.handle.net/10316.2/44044

DOI:

DOI:https://doi.org/10.14195/0871-9527_26_12

Accessed : $\quad$ 26-Apr-2023 12:25:21

A navegação consulta e descarregamento dos títulos inseridos nas Bibliotecas Digitais UC Digitalis, UC Pombalina e UC Impactum, pressupõem a aceitação plena e sem reservas dos Termos e Condições de Uso destas Bibliotecas Digitais, disponíveis em https://digitalis.uc.pt/pt-pt/termos.

Conforme exposto nos referidos Termos e Condições de Uso, o descarregamento de títulos de acesso restrito requer uma licença válida de autorização devendo o utilizador aceder ao(s) documento(s) a partir de um endereço de IP da instituição detentora da supramencionada licença.

Ao utilizador é apenas permitido o descarregamento para uso pessoal, pelo que o emprego do(s) título(s) descarregado(s) para outro fim, designadamente comercial, carece de autorização do respetivo autor ou editor da obra.

Na medida em que todas as obras da UC Digitalis se encontram protegidas pelo Código do Direito de Autor e Direitos Conexos e demais legislação aplicável, toda a cópia, parcial ou total, deste documento, nos casos em que é legalmente admitida, deverá conter ou fazer-se acompanhar por este aviso.

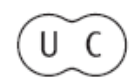




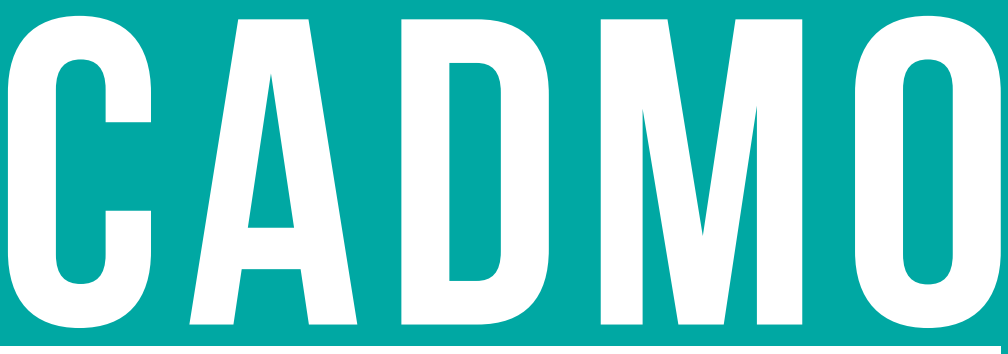

REVISTA DE HISTÓRIA ANTIGA JOURNAL FOR ANCIENT HISTORY

26

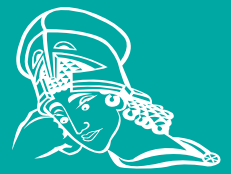

CENTRO DE HISTÓRIA DA UNIVERSIDADE DE LISBOA 2017 
Um estudo evoca a rainha Ešarra-hammat, mãe do rei Assurbanípal II, explorando a possível utilização do seu fantasma na consolidação do poder do famoso soberano assírio. Miriam L. I. Silva discorre sobre a biografia de Santa Radegunda de Poitiers (século VI), escrita pela monja Baudonívia do Mosteiro de Santa Cruz de Poitiers, que aquela princesa franca fundara. Maria do Carmo P. Santos tenta retratar a condição da mulher muçulmana, mencionando as divindades anteriores ao Islão de Maomé para ilustrar a protecção que a legislação corânica terá representado para o mundo feminino muçulmano. Não deixa, contudo, de sublinhar a dificuldade de um trabalho desta abrangência, já que a extensão do mundo muçulmano e suas especificidades regionais exigem investigação muito mais aprofundada e direccionada para as diferentes sociedades islâmicas ao longo do tempo nos respectivos contextos.

Também Paulina Nólibos recorre a uma tragédia de Eurípides (As Bacantes) para tratar o fenómeno das ménades, que contrapõe como mulheres livres às mulheres gregas tradicionais, "fiéis às expectativas do papel social do seu sexo" (p. 292). Vicente Dobroruka faz um interessante trabalho, que ressalva à partida não se tratar de uma abordagem de género, sobre a suposta figura feminina presente nos Oráculos Sibilinos, a qual discorre abertamente sobre a sexualidade e o casamento.

Apenas um estudo é dedicado a uma deusa, o de Maria Cecília Colombani sobre Ártemis. Tendo presente uma das problemáticas enunciadas no prefácio, seria interessante encontrarmos mais trabalhos dedicados a outras deusas da Antiguidade, além da Magna Mater referida por Claudia Beltrão da Rosa quando narra o mito sobre a figura de Claudia Quinta, assim como sentimos a ausência da Pitonisa de Delfos no campo da profecia ou mesmo de uma das Sibilas gregas.

A obra, que beneficiaria com uma revisão cuidada (já que são muitas as gralhas tipográficas), é na realidade um mosaico de pequenos tratados que podem constituir um bom ponto de partida para o aprofundamento dos temas e, nomeadamente, para uma perspectiva mais abrangente na historiografia de género, cada vez mais actual.

Maria Fernandes

Centro de História, Centro de Estudos Clássicos, Faculdade de Letras, Universidade de Lisboa

ADRIENNE MAYOR (2014), The Amazons: Lives and Legends of Warrior Women across the Ancient World. Princeton, Princeton University Press, 536pp. ISBN: 978-0-691-17027-5 (Hardcover: £24.95;

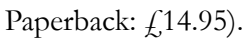

At the beginning of the book, Mayor (M.) refers to her work as an "encyclopaedia Amazonica", a compendium of everything related to Amazons. This is, in my opinion, the best short description of this book, since, to my knowledge, there is no study of Amazons more complete than this one - a very extensive book (536 pages, providing almost one hundred illustrations), divided in four major parts.

The first part, entitled 'Who were the Amazons', provides an initial insight to the complexity of the topic that will be deeply explored in part two. It is an extended introduction to the topic, presenting the difficulties in navigating through the Greco-Roman sources on the subject, presenting some of the non-Greek sources approached in the book, explaining the problematics that the author 
will explore in this study. It is already clear, in this first part, that this is a cross-disciplinary study that will be amply based on solid evidence. M.'s arguments for the historicity of Amazons are largely based on archaeological readings, but also providing a wide range of literary sources, from Greek to Chinese literature, and sometimes providing an anthropological view, complementing her ideas with the study of Asian and African societies. From the beginning, M. introduces her view of Amazons as historical, considering the warrior women, from nomadic horse based societies, such as Scythia (that M. names the 'Amazon Homeland'), at the source of inspiration for the Greek conception of Amazons; societies marked by an egalitarian status between women and men. Chapters 2 and 3 are dedicated to explain not only who the Scythians (and the Sarmatians, supposedly descendants from Amazons) actually were, but the Greek perception of them.

The second part is, in my opinion, the most remarkable part of the entire book. Here, M. sets to investigate who these warrior women were, producing an extremely thorough piece of scholarship, amply based on archaeological evidence, although never disregarding literary sources. In Chapter 4, M. explores the physical remains, namely graves of warrior women found from the western black sea to China, for more than one thousand years; analysing an impressive number of graves where skeletons of women were deposited, often showing injuries suffered from combat and horse-riding. These women were commonly found with weapons, spears, swords and arrow heads. One of the most impressive discoveries, in my opinion, was a pair of warrior women in Britain. Chapter 5 deals with the historicity of the most famous detail of Amazons - the removal of the right breast in order to wield the bow. As A. states, "It is the one thing everybody "knows" about Amazons". The idea is easy refutable, considering that the mechanics of actually shooting an arrow demands the string to be pulled to the level of the cheek, instead of pulling it against the chest. As the author rightly notices, Artemis is a female archer with two breasts. She shows how this notion lacks fundament, deconstructs the validity of the etymologic value of the term Amazones as "breastless" and provides examples that counter this theory, although also seeking to find an answer to why the removal of the breast became the most famous physical feature of Amazons, exploring ancient rituals of breast constraining. Chapter 6 is an important addition to the study of tattoos in antiquity. M. starts with the analysis of the tattooing tradition among Thracian warrior women, moving to an analysis of tattooed women from near and far eastern societies, debating the importance that tattoos had as a preserver of mythological traditions among oral societies. Chapter 7 explores representations of naked Amazons and their erotic value and uses; Chapter 8 discusses the sexuality of Amazons and chapter 9 focuses on their use of drugs and their musical-dancing traditions. In Chapter 10, entitled "The Amazon way", M. provides insight into the amazon family and the life of the steppes societies, such as their ruling system and religion. She continues to demystify some of the most famous rumours concerning amazons, such as the killing of male babies, arguing in favour of an egalitarian status between men and women in amazon societies. As M. notices, there is no archaeological evidence of intentional maiming of young males. Most of the injuries perceivable through the analyses of the skeletons result from their violent lifestyle; however, such injuries are found both in male and female remains. Chapter 11 explores the role of animals in Amazon's culture, obviously emphasizing the role of the horse, a crucial element for the daily life of amazon's culture. Chapter 12 deals with amazon garments, more specifically the usage of trousers, showing it as a symbol of the egalitarian status of horse-people societies, another differential element from Greek societies where trousers were not an admissible 
garment. Chapter 13 explores Amazon's manufacturing of weapons, armour, and how they used them, starting by addressing their fame as bow builders and wilders. Chapter 14 moves us away from the general conception of Amazons and focuses the reader on questions that usually are not asked: what language did the Amazons actually speak, and did they have a writing system?

The third part deals with the presence of Amazons in Greco-Roman mythology and historical accounts. Starting by exploring the mythological corpus, M. moves from the amply based archaeological approach from the second part (although without disregarding literary sources), and delves entirely into the Greco-Roman conception of Amazons. Although M. keeps providing her own views on the topic, it is a much more narrative chapter. It is an amazing compendium of Greco-Roman myths concerning the Amazons; however, it lacks the freshness and scientific impact of the second part. M.'s analysis of the Greco-Roman historical sources is, in my opinion, more daring than the previous, especially chapter 20, where she explores the account of Alexander the Great and Thalestris, approaching the episode through every possible angle, showing that, although we do not possess enough evidence to deem it as completely true, we have enough grounds to consider it plausible.

The fourth part is dedicated to explore the existence of warrior women from the Caucasian steppes to China, analysing their presence in Persia, Egypt, North Africa, Arabia and central Asia. It is very good piece of research, exploring a wide range of sources that cross an incredible amount of different cultures.

Despite the excellency of M.'s research, it is fair to pose the following question: should we name all warrior women 'Amazons'? M. sometimes seems to be aware of the problem with the nomenclature by choosing to apply the term 'warrior women'; however, she does use the term 'Amazon' as a synonym quiet often. Is being knowable in the art of war the single premise to be an Amazon? The fact that we do not know the actual etymology of the term Amazones makes it more difficult to actually know where it might be correctly applied, however, even if the term is not originally Greek, we do tend to apply it in the same way the Greeks did. Although there are disparities in Greek sources, they had a general conception of Amazons as a society of women, which is not what M. presents, since she presents us warrior women that lived with men, sharing the same status.

I do also believe that this study lacks a chapter considering the presence of Amazons in modern culture. Xena, the warrior princess, and Wonder Woman (although she approached the DC heroine in recent post in the Princeton University Press Blog) are just two examples of the influence that Amazons still have today. Nevertheless, M.'s book is, in my opinion, the most complete piece of scholarship on this topic, relevant either for the classics researcher, student or the general public. It is more than a study of Amazons per se, but rather an important study of a specific sort of women. It is a crucial study of Amazons, but extremely relevant to the study of women in the ancient world.

José Malheiro Magalhães

Centro de História, Faculdade de Letras, Universidade de Lisboa University of Roebampton 